\section{Adventures of Ben Trovato}

Walter Gratzer

Discovering: Inventing and Solving Problems at the Frontlers of Scientific Knowledge. By Robert Root-Bernstein. Harvard University Press: 1989. Pp. 501. \$35. To be published in Britain next month, £27.95.

Fortune or Fallure: Missed Opportunities and Chance Discoveries in Science. By Alexander Kohn. Basil Blackwell: 1989. Pp. 199. £14.95, \$24.95.

Serendipity: Accidental Discoveries in Science. By Royston M. Roberts. Wiley: 1989 Pp. 270. Hbk \$19.95, £13.30; pbk \$12.95, £8.65.

Harrap's Book of Sclentific Anecdotes. By Adrian Berry. Harrap, London: 1989. Pp. 240. £12.95.

MurPhy's law, or as the French call it, le loi d'emmerdement maximum, dictates that when we drop the breakfast toast on the newspaper or floor it always falls spread-side down. Imagine now recovering the errant morsel and finding, when you turn it over to scrape away the bits of carpet, the long-lost contact lens embedded in the marmalade. This, according to Royston Roberts, is serendipity. Consider next the case of the American professor of statistics, who observed that when his children dropped their bread and butter on the carpet it always landed buttered-side up. A violation of Murphy's law? By no means, for on looking into the matter more closely the professor found that his children were buttering their bread on both sides. This Dr Roberts calls pseudo-serendipity - an unsought discovery that comes to reward the deserving, those whose minds are equipped to receive and interpret the signal, who descry that tide in the affairs of men, which taken at the flood leads on to fortune.

Should you feel impelled to buy these four books, you will learn, not once but four times, that serendipity is a coinage of Hugh Walpole's, derived from the Persian fable of The Three Princes of Serendip (that is to say Ceylon, or if you prefer, Sri Lanka), meaning the happy faculty of making unexpected and fortunate discoveries. Robert Root-Bernstein explores the phenomenon in the greatest depth and his is by far the most ambitious work. It is cast in the form of a running seminar, for six voices, about the nature of the scientific process. One of these, referred to as Imp, I take to be the author's alter ego. The discussion ranges over the practice, philosophy, organization and sociology of science with no little erudition, even if one occasionally fancies that one is being beaten about the cranium with it ("As Paul Valéry says..."). Imp and his friends develop many a provocative but abundantly documented thesis. Science, they find, for example, is getting worse: ever more scientists are generating less and less new knowledge per head; the success of science at the national level does not reflect the munificence of its funding. Many small countries - Den- mark is one - do better than the United States, let alone the Soviet Union, by such criteria as Nobel prizes per head of population.

Root-Bernstein's protagonists argue a great deal about creativity. How may it be promoted and can it be taught? The uneasy outcome seems to be that it can be inculcated by educational precept,

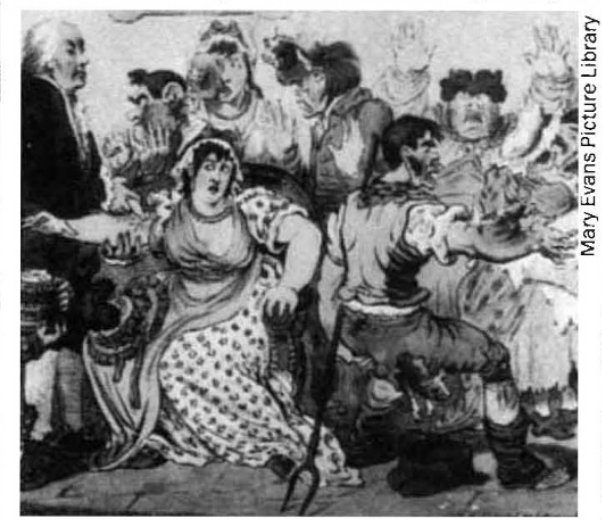

Contemporary mistrust of Jenner's theory. according to such formulae as used to be advertised by Edward de Bono; the existence of the great scientific dynasties - Nobel laureates begetting Nobel laureates - suggests, on the other hand, that it is better learned by example, as part of the patrimony of a great laboratory.

Root-Bernstein illustrates his argument with many examples. He favours research by bold and hazardous flights of the intellect: to be audaciously wrong is better than to be timidly correct. ("This theory isn't right", Debye was supposed once to have declared after a seminar, "it isn't even wrong".) Imp is ever keen to challenge the wisdom of the day. Crick's Central Dogma is his favourite target. But here the urbane mask suddenly slips, revealing, as it seems, a bloodshot glint of messianic fire; for it is Root-Bernstein's own work (published in the Journal of Theoretical Biology) that his surrogate cites in evidence. He is out to black the Establishment's eye by breaching the infamous Central Dogma with a demonstration that information can flow from protein to protein. Model building leads him to a scheme of complementary amino acids. In search apparently of a spot of serendipity, he meanders down a byway and arrives at a model for an interaction between a neurotransmitter, serotonin, and myelin basic protein. Imp speaks highly of Root-Bernstein's work. He then goes on to denounce the intolerance of the guardians of entrenched opinion towards such enterprising conceits as fourstranded DNA structures, and the purblind reluctance of grant committees to shell out money for the pursuit of heterodoxy. I find this slightly queasy reading: it seems to me to come close to the cry of the crackpot down the ages, demanding a blank cheque to support what Irving Langmuir called (with criteria by which it could be recognized) pathological science.

Root-Bernstein quotes with approval Albert Szent-Györgyi's remark about the fatuity of a system of funding that required of him some indication of what he proposed to do with the money. If, he maintained, he knew what he was going to discover, there would be no need for him to discover it. Judged by this argument of course all discoveries are by their nature serendipitous. But Root-Bernstein goes on to make a compelling case that the grant system is becoming increasingly rigid, and acts to discourage those digressions in pursuit of the unexpected that have so often led to the most striking discoveries. His analysis of conceptual upheavals in science over the past century or so also leads him to the conclusion that a large proportion have come from unknown researchers, operating alone in the geographical wilderness. If he is right then the cultivation of 'centres of excellence' and the projected elimination of research from minor seats of learning in Britain are a dangerous folly. Our scientific mandarins should examine his evidence with care.

Another of the contentions ventilated by Imp and his companions is that the creative process is nourished by artistic imagination, and that the scientific elect most often possess accomplishments in music, in painting or in poetry. The evidence is marshalled in a table that spreads itself over several pages. This may be right, but for my part I have too often found the giants of our profession to be boorish thugs to be wholly convinced. Moreover, while there may be no doubt about Einstein's love of music, his proficiency on the fiddle by all accounts did not far outstrip that of Heifetz in cosmology. (His frequent partner, Martinu, who wrote a sonatina for him, was supposed to have snapped in exasperation: "Damn it, Einstein, can't you count?")

But enough grousing, for Root-Bernstein has written an absorbing, stimulating, sometimes infuriating book, full of entertaining ideas, and everyone with an interest in science and its ways will benefit from reading it. 
Alexander Kohn and Royston Roberts plough the selfsame furrow. All the old tales are here, nor do they fade with the telling, and there are also a good many I did not know. Both miss the story of Dr Murphy's patient in Boston, who was fond of raw liver and became cured of pernicious anaemia, but not much else that I could think of. Kohn concentrates more on medical discovery, and in today's world of mandatory LD50 tests, clinical trials and FDA approval, the casual manner in which dire procedures were tried on human subjects - the family, often enough, of the experimenter - taxes credulity. Jenner, it may be remembered, "with great fortitude tried the cow-pox on his wife and children", but before that he had taken the precaution of inoculating a farm-boy, James Phipps, and then injecting him with the real article - a smallpox extract. Much more recently a research director at Boehringer, screening a series of compounds for vasoconstrictor activity to use against the common cold, tried one out on his snuffling secretary; she promptly sank into a sleep that lasted 24 hours, and her bloodpressure was found to be alarmingly low. By this means clonidine, the sovereign treatment for hypertension, was discovered.

In the drug field, especially, the exercise of reason seems to have played little part in the best discoveries. Lithium therapy is an example to make any rational pharmacologist put by his smoked drum and seek a tranquil retirement. Kohn tells the story well: an Australian psychiatrist conceived the notion that manic disease was caused by a toxin, and that this would appear in the urine. So he injected the urine of his patients into guinea pigs. The guinea pigs reacted badly, but less so, he judged, to control urine. The next stop was to identify the toxic principle. Urea killed the guinea pigs, but its concentration was the same in manic and normal urine. How about uric acid then? But free uric acid is insoluble, so the dauntless experimenter prepared the lithium salt. Not only did it appear innocuous, but it counteracted the toxicity of urea and exerted a 'calming effect' on the agitated rodents. To do the psychiatrist justice, he did then ask himself whether it was the uric acid or the lithium that was exerting the benign affect, and indeed lithium carbonate proved equally soothing. He now tried lithium carbonate on a patient, with miraculous results. A paper was written and ignored until it was discovered in the fringe literature by a Danish worker some years later. Lithium therapy became in due time one of the

\section{In Memoriam}

or "quaker", pray, and for "moth-eaten", mourn. his threnody recalls their fate forlorn.

We catered to their reproductive need. We cherished and encouraged them to breed. We nourished them (for 15 cents a day) ntil, on orders, they were shipped away:

Their natures chromosomally imbued With genes for "non-immunity" or "nude", rom whites to pure $\mathrm{C}-57$ blacks:

thousand, thousand cultivated JAX.

In two score years and two, that realm of mice, Felled once by fire, has now been stricken twice, gnited by explosion of propane

To holocaust in far Bar Harbor, Maine,

Where, cage on cage, in box on burning box, There perished scores of rare foundation stocks. On shelf and bench, in closely serried racks, There died a pyre of martyred murine JAX.

Weep, then, for mice in Roscoe Jackson's name, ncinerated in a burst of flame.

Like fair Brunhild', by fiery circle girt,

They died, the noblest breeds of Mount Desert. Their bodies ashed, their genes distilled away -

Mourn for "moth-eaten", and for "quaker", pray!

Ralph A. Lewin across the windpipe with the other arm? Roberts believes they are just like us, only quicker of wit and sharper of perception. For every one of them there must be a thousand others, who failed to take the tide at the flood, and the voyage of whose lives was accordingly bound in shallows and in miseries.

Kohn enlarges on the subject of missed opportunities. These tales are inevitably harder to come by, but he tells for example of a wellknown biochemist, still among us, who went to the wrong seminar and failed to initiate a collaboration which would probably have started recombinant DNA a year or two early. He might have mentioned also the Japanese physicist, who shelved an observation that should have led him to the discovery of the neutron; it was said that in his later years cruel students would drop the word in his presence to see the tears well up and course down his cheeks. But what of all the discoveries and inventions that have not been made? Like children unconceived, they will never be missed, but one can imagine them massing in the shadows to mock the bureaucrats who work so hard at great triumphs of clinical science; but manic patients have no toxin in their urine and the guinea pigs became quiet only because the lithium made them sick.

Roberts is an organic chemist and his trade is perhaps the richest of all in fortuitous and perverse discoveries. $\mathrm{He}$ has written an entertaining book, accessible to all. Here is Dr Sapper, who breaks a thermometer in the reaction vessel and is rewarded by the discovery that mercuric ion is a catalyst for the oxidation of naphthalene to phthalic anhydride, and so begets the modern dyestuff industry. Roy Plunket, in search of a better refrigerant, sets out to try a prep with tetrafluoroethylene. The weight of the gas cylinder shows it to be full, but nothing comes out. On being sawn open it yields up a waxy solid, now known as Teflon. A negligent graduate student leaves his cigarette smouldering on the bench while he works; he takes a drag and finds that it tastes intensely sweet. He has discovered saccharine. Forty years later James Schlatter at Searle, pursuing ulcer drugs, is synthesizing a terminal dipeptide of gastrin. He licks his fingers and experiences a sensation of sweetness. He tastes his dipeptide ("It was a bold man who first swallowed an oyster", said King James), and lo, aspartame or Nutrasweet is the fat man's friend. And so it goes.

Who are these holy innocents, whose curls fortune ruffles with her fingers, while giving the rest of us the flat of the hand keeping scientists away from the paths of dalliance. supposed to have addressed the following exhortation to his assembled family: "If you want to die as rich as I am, never brighten up The Daily Telegraph". But do not let this put you off Harrap's Book of Scientific Anecdotes, which comes from the pen of the Telegraph's science correspondent. The book is not what its title suggests, but rather a collection of Adrian Berry's favourite passages of scientific and technological journalism, yarns of discovery and exploration from The New Atlantis to Chernobyl. It is agreeably written, spiced with witticisms and altogether good fun.

I shall leave you with just one example of Berry's historical research. It concerns the reception given to Alexander Graham Bell's telephone. The mayor of an American city grasped its potential at once: "One day", he said, "there'll be one in every city". But what did the experts think? Here is the Chief Engineer of the British Post Office, reporting with considered wisdom to a House of Commons committee: "Americans have need of the telephone - but we do not. We have plenty of messenger boys". So much for peer review.

Walter Gratzer is in the MRC Cell Biophysics Unit, King's College London, 26-29 Drury Lane, London WC2B 5RL, UK.
On his deathbed, Lord Camrose was 